Working

Paper

Department

of Economics

Ca’ Foscari

University of

Venice

Giovanni Favero

Benetton: identifying an image, imagining an identity 


\title{
Benetton: identifying an image, imagining an identity
}

\author{
Giovanni Favero \\ University of Venice
}

\begin{abstract}
This paper deals with the Benetton's approach to advertising and with the changes in the image of the company since its foundation in 1965 up to the 2000s. Links among the evolution in promotional, distributional and productive strategy are discussed.
\end{abstract}

The paper has been presented at the European Business History Association conference on Corporate images - Images of the corporation, held in Frankfurt, September 1-3, 2005.

It will be submitted to the Paris-based journal Entreprise et histoire.

\section{Keywords}

business strategy, image policy, franchising

\section{JEL Codes}

N840, M370

Address for correspondence:

Giovanni Favero

Department of Economics Ca' Foscari University of Venice Cannaregio 873, Fondamenta S.Giobbe 30121 Venezia - Italy

Phone: (++39) 0412349165 Fax: (++39) 0412349176 e-mail: gfavero@unive.it

This Working Paper (o QD se in inglese) is published under the auspices of the Department of Economics of the Ca' Foscari University of $V$ enice. Opinions expressed herein are those of the authors and not those of the Department. The Working Paper series (o QD se in inglese) is designed to divulge preliminary or incomplete work, circulated to favour discussion and comments. Citation of this paper should consider its provisional character.

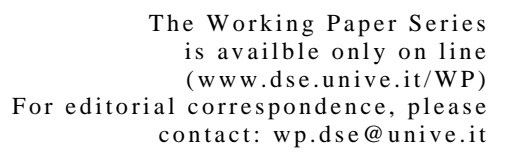

he Working Paper Series is availble only on line contact:wp.dse@unive.it
Department of Economics

Ca' Foscari University of Venice

Cannaregio 873, Fondamenta San Giobbe

30121 Venice Italy

Fax: ++390412349210 


\section{Benetton: identifying an image, imagining an identity}

1. Benetton's story is well-known (Nardin 1987, Belussi 1989, Benetton-Lee 1990, Mantle 1998, Favero 2005). The company was born in 1965 in Ponzano Veneto (in the Treviso province), from the artisan knitting workshop of the Benetton siblings. In the 1970s it expanded in the Italian market of sweaters and soon of casual apparel in general. In the 1980s sales extended all over Europe, to USA and Japan. Internationalization stirred up a logistic and managerial reorganization, while the company went floating in order to support investments. In the 1990s, unsuccessful attempts to enlarge product range were followed by family-led acquisitions in other sectors (Brunetti-Bortoluzzi 2004).

This quick survey suggests a growth path involving important changes, affecting both company image and identity. This paper aims to investigate precisely the relationship between image and identity in Benetton's evolution. The image of a company reflects its strategic approach to competition, market, and the wider social context. Still, its image inevitably affects also the 'black box' of its internal procedures and organization. It is possible to say that the language used in communication affects the way a company thinks its identity and adapts its structure to this. 
2. In the 1960s and the 1970s, Benetton's promotional strategy was focused on shops, advertising huge expenditures being out of reach at the time.

The first 'My Market' shop format was designed by Tobia Scarpa, son of the famous architect Carlo Scarpa. He suggested to eliminate the counter, arrange all the sweaters on shelters, and open the window towards the interior of the shop. This way, the same room could be used for stocking, selling and displaying merchandise (Heskett-Signorelli 1985). Most of the shops were not company-owned, but informally franchised to shopkeepers paying no royalties and granted no exclusive right. Independent agents recruited franchisees and collected their orders. The presence of several shops in the same urban area produced a positive iteration effect on final customers, and a dissuasive effect on competitors. The creation of a franchisee-shops network selling many-coloured classical-cut sweaters (serially weaved, sewed outside, and then dyed) can explain the competitive advantage the 'Benetton formula' enjoyed since the late 1960s.

In the 1970s, the company started producing also jeans and velvet trousers, shirts and T-shirts, in order to allow customers to find a coordinate set of apparel inside its shops. With its combinable collections, Benetton helped developing Italian casual style. Product differentiation brought about target differentiation, and a multiplication of shop formats as '012' for kids, 'Merceria' for young customers' mothers (Benetton-Lee 1990, 12), 'Jean’s West' for jeans, or 'Tomato' for penniless young people, and others. Benetton's name never appeared on the sign of the shop, but only on single items (with the wool-knot logo that became famous in the 1980s). Low visibility allowed not to alarm competition, and marked off the company from shopkeepers commercial policies.

Still, there was something more. In the 1970s Benetton actually aimed to conceal its expansion, in order to escape social and political tensions, prevent unions from meddling with its informal production and distribution network, and keep on moving as a little family business despite its growth. Luciano Benetton effectively summarizes the reasons for this 
choice: «The pressures put on it by the Seventies made Benetton a chameleon. (...) A company so lucky it made profits in so troubled years, had to keep on purpose a low-profile line, and to camouflage itself in the environment. Therefore, we made few advertising campaigns, we carefully avoided showing off, and we escaped any political connection. (...) We took great care to be invisible. No interviews, no propagation of financial data obviously, in observance of the laws. (...) The public could not perceive our actual dimension and circulation, both industrial and commercial» (Benetton-Lee 1990, 110).

3. At the end of the 1970s Benetton met its first difficulties in sales. This crisis made the entrepreneurs aware the company had reached a threshold in scale, and that a reorganization was needed in order to avoid a downsizing. Awareness came along tentatively, buying and then selling shops and plants, and trying to expand in Europe in order to make up for the saturation of Italian market. This learning phase was useful to define company identity according to its specific resources and the elements which had brought it to success. Indeed, it was only in the attempt to expand sales abroad that franchising was used on purpose to enter new markets, and became the driving element of a new strategy for growth.

What strikes more is the radical change in the image policy. From the low-profile attitude of the 1970s, Benetton moved in the 1980s towards an explicit brand promotion and an increasing transparency, in view of listing on the stock exchange. Sales promotion abroad needed to use the Italian-style appeal of Benetton name; in Italy too, Benetton unified different existing shops under the Benetton, 012 and Jean’s West signs: too much differentiation threatened to frustrate brand-advertising efforts. Visibility was also a result of the choice to take family-business clothes off, and to turn Benetton into an international company with solid relationship with politics and finance. Thanks to its camouflage ability, in the 1970s the company had been able to enjoy State facilities without undergoing the limitations big businesses suffered. In the different political context of the 
1980s, it became a respectable interlocutor for national institutions, politicians and bankers.

In the second half of the 1980s, the success of commercial expansion in Europe urged an adjustment of international strategy. Western Europe had become Benetton's real domestic market, and the 1987 annual report praised European unification but also stated that product 'globality' was a strategic asset, a value 'for company management, and an inspiring idea for all protagonists and collaborators of Benetton Group'.

To expand sales in Asia or in the Americas (and in other products), Benetton adopted a new step-by-step entry strategy, firstly licensing local producers to use its trade mark, then entering in joint venture with them, and establishing a local branch of the company only when the market had shown its development capacity. In this project, brand promotion was a basic point: advertising expenditures increased then more, in order to promote a coloured, multi-ethnical and global image of the company.

Since 1983 advertising design had been entrusted to the Parisian agency Eldorado, employing the photographers Bruno Sutter and Oliviero Toscani. In the 1984 campaign 'All the Colours of the World' Toscani put together white and black young models wearing coloured clothes. He introduced then the 'United Colors of Benetton' slogan, explicitly identifying the company's globalization strategy with the ideal of a peaceful, multi-ethnical world, which after the international political changes of the second half of the 1980s seemed at hand. In 1989 this slogan became the logo of the company, and Toscani was hired by Benetton, breaking the contract with Eldorado.

In the following campaigns, any reference to the product disappeared, and advertising focused on topical social issues. Toscani's 'shock' campaigns disconcerted for the subject of images, such as the nunand-priest kiss, or for the timing of their publication, as for the warcemetery photo circulated on occasion of the Gulf-War outbreak. Toscani and Benetton claimed for the photographer and for the company the right to deal with the reality issues usually expunged from the fictitious world of 
advertising. Indeed, polemics on the press came to emphasize the visibility of the company and its presumed social commitment (Falcinelli 1999; Pinson-Tibrewala 1996).

4. The inflation of Benetton's image in the first 1990s was also enhanced by the success of the Formula 1 stable the company acquired in 1984, which in 1994 and 1995 won the World Championship (Mantle 1998). The company also owned basket, rugby, volley and water-polo teams. In 1992 Luciano Benetton stood as candidate for and was elected to Parliament, with a move allowing him an insider knowledge of economic policy decisions in those troubled years for Italy, and putting again his company in the limelight.

Indeed, troubles were not only for policy makers: in the 1990s Benetton's market position was challenged by international retailers such as The Gap and Zara. Company reacted by adjusting the dimensions of shops to the need of a total-look offer including licensed apparel and accessories, from spectacles to cosmetics. Average shop area increased from 50 to 200 square meters, and new megastores were opened in big cities all over the world. The megastore project forced the company to buy valuable real estate in order to fill strategic commercial positions; still, in perspective also megastores were to be franchised to independent shop owners.

Even facing retailers' competition, Benetton went on acting as an exclusive wholesaler for its franchisees. This strategy allowed more flexibility and shifted on shopkeepers most of market risks. The growing conflict between sales expansion and profits was then solved this way in favour of profitability (Camuffo-Romano-Vinelli 2001).

Still, the relationship between the company and its franchisee shopkeepers allowed them some room for autonomy and resistance, as in every network organization (Powell 1990). In 1984, Benetton was planning to build up a communication system collecting both orders and payments from franchisees' sales records. This project failed because of the (mostly 
passive) resistance shopkeepers and agents offered to what they saw as a threat to their autonomy (Rullani-Zanfei 1988).

Even if they succeeded in defending their managing independence, shopkeepers were never allowed to meddle in company's brand policy. When sales slumped in European markets in the first 1990s, shopkeepers (who could not return unsold goods) blamed Toscani’s 'shock' campaigns for alienating customers, going so far as to sue the company for that, but lost the case. It is interesting to confront this episode with the completely different outcome of the 2001 conflict on the 'death row' campaign. On this occasion, the department store chain Sears, Roebuck \& Co. rescinded the distribution agreement with Benetton it had entered into in 1998. Toscani resigned in 2002.

The case pointed out some implications of commercial relationship the company seem not to have perceived. In its relationship with big retailers, Benetton did not enjoy the same position of strength which allowed it to impose its promotional choices to franchisee shopkeepers. Brand policy could not leave out of consideration the eventual reaction of different commercial partners. Not only money, but also power concerns persuaded Benetton not to change its approach to distribution, even if its 'flexible formula' (Benetton 1994) in last years turned out to be very rigid, when compared with international competitors' quick-response ability based on the control of their chain shops (Edmonson 2003, Barela 2003). 


\section{Works cited}

M.J. Barela, 'Executive insights: United Colors of Benetton. From sweaters to success: an examination of the triumphs and controversies of a multinational clothing company', Journal of International Marketing, 11 (4), 2003, 113-128.

F. Belussi, 'Benetton: a case study of corporate strategy for innovation in traditional sectors', in M. Dogson (ed.), Technology strategy and the firm: management and public policy, London: Longman 1989.

L. Benetton, A. Lee, Io e i miei fratelli: la storia del nostro successo, Milano: Sperling \& Kupfer 1990.

L. Benetton, 'Franchising: how brain power works', in P. Stobart (ed), Brand Power, London: MacMillan 1994.

Benetton Group, 1987 Annual Report.

G. Brunetti, P. Bortoluzzi, Benetton: da United Colors a Edizione Holding, Milano: Isedi 2004.

A. Camuffo, P. Romano, A. Vinelli, 'Back to the future: Benetton transforms its global network’, MIT Sloan Management Review, 43 (1), 2001, 46-52.

G. Edmondson, 'Has Benetton stopped unraveling?’, Business Week, 3839, June 30, 2003, 76.

L. Falcinelli, Pubblicità paradiso: la company image del Gruppo Benetton, Milano - Perugia: Lupetti - Università per stranieri di Perugia 1999.

G. Favero, Benetton: i colori del successo, Milano: Egea 2005.

J. Heskett, S. Signorelli, 'Benetton', Harvard Business School Case n. 0685-020, Cambridge, MA: Harvard Business School 1985.

J. Mantle, Benetton: the Family, the Business, and the Brand, London: 1998.

G. Nardin, La Benetton: strategia e struttura di un'impresa di successo, Roma: Edizioni Lavoro 1987. 
C. Pinson, V. Tibrewala, 'United Colors of Benetton', in J.K. Johansson (ed.), Global marketing: foreign entry, local marketing, and global management, New York> McGraw-Hill/Irwin 1996, 556-567.

W.W. Powell, 'Neither market nor hierarchy: network forms of organization', Research in Organizational Behavior, 12, 1990, 295336.

E. Rullani, A. Zanfei, 'Networks between manufacturing and demand: cases from textile and clothing (Benetton, Miroglio, GFT)', in C. Antonelli (ed.), New information technology and industrial change: the Italian case, Dordrecht: Kluwer Academic 1988, 57-95. 